\title{
Integrating Traditional Ecological Knowledge and Fisheries Management in the Torres Strait, Australia: the Catalytic Role of Turtles and Dugong as Cultural Keystone Species
}

\author{
$\underline{\text { James R. A. Butler }}^{1}$, Alifereti Tawake $^{2}, \underline{\text { Tim Skewes }}^{1}, \underline{\text { Lavenia Tawake }}^{1}$ and Vic McGrath $^{3}$
}

\begin{abstract}
In many developing regions of Melanesia, fishers' traditional ecological knowledge (TEK) has been integrated with western science and management knowledge (SMK) to generate innovative and effective fisheries management. Previous research suggests that three factors initiate this process: depleted fishery stocks, limited SMK, and ownership of resources by local communities. In other contexts the extent of power-sharing through comanagement, and the cultural significance of species may also be important determinants of knowledge integration. Here we assess the role of these factors in the application of TEK in the Torres Strait Islands, Australia, where commercial and subsistence fisheries are fundamental to the Indigenous Melanesian culture and livelihoods. In 2009 we surveyed fishery managers and scientists who revealed that TEK had only been recently and sparingly applied in four fisheries (turtle, dugong, lobster, and hand collectables), and only two of the seven species concerned had a combination of depleted stocks, low SMK, and high community ownership. Instead, comanagement characteristics and the cultural value of species were the primary determinants of TEK application. We suggest that turtles and dugong are cultural keystone species that simultaneously provide important ecosystem services to both islanders' livelihoods and international conservation interests. Combined with their ecological scale these species have catalyzed comanagement between indigenous and government stakeholders, precipitating the application of TEK in other fisheries of lesser cultural importance. We discuss modifications to governance required to enable knowledge integration to evolve further through adaptive comanagement, and its role in enhancing fisheries management and thus the resilience of the Torres Strait social-ecological system. Our study highlights the potential utility of cultural keystone species in stimulating cross-cultural resource governance in developed economies such as Australia.
\end{abstract}

Key Words: adaptive comanagement; climate change; ecosystem services; dugong; governance; livelihoods; Melanesia; Papua New Guinea; resilience; subsistence fisheries; traditional ecological knowledge: turtles

\section{INTRODUCTION}

Globally there is recognition of the valuable role that traditional knowledge held by indigenous communities, often termed traditional ecological knowledge (TEK), can play in the contemporary management of natural resources. TEK is characterized by practical skills and wisdom developed at a local scale through earning livelihoods from the environment over successive generations (Berkes 1999, Brook and MacLachlan 2008). TEK can be conceptualized as different levels in a nested knowledge-practice-belief complex (Berkes 1999). Local knowledge of species, their life histories, distributions, and behavior are nested within resource management systems, tools, and techniques. In turn, these are embedded within the social institutions, codes and norms required to implement management systems, and a worldview that shapes environmental perception.

When TEK is integrated with western science and management knowledge (SMK) the resulting epistemological pluralism potentially enhances the resilience of socialecological systems by providing a diversity of knowledge for problem solving (Folke 2004, Folke et al. 2005, Berkes and Turner 2006, Davidson-Hunt 2006, Berkes 2009, Bohensky and Maru 2011). TEK can contribute place-based, fine-scale spatial and temporal information, management techniques, and institutions, whereas SMK provides understanding of contemporary large-scale ecological processes historically not encountered by TEK (Moller et al. 2004, Aitkenhead and Ogawa 2007, Wohling 2009). In fisheries management, TEK can complement SMK by providing long-term baselines for stock assessments, local knowledge of species' ecology and behavior, habitat conditions and trends, plus customary management systems (Johannes et al. 2000, Dulvy and Polunin 2004, Haggan et al. 2007, Johannes and Neis 2007).

Tropical inshore marine fisheries present a particular opportunity for the application of TEK. They are typically small but complex social-ecological systems, involving a wide range of species taken for both subsistence and commercial use primarily by local fishers within diverse property regimes (Pinkerton 2009). Conventional centralized, command-andcontrol governance is often under-resourced and too inflexible to provide the fine-scale management required (Johannes 1998a, Wilson et al. 2006). In many developing Melanesian regions of the Pacific there has been a renaissance of customary management in response to this problem, for example in Fiji, 
the Solomon Islands, Papua New Guinea, and Vanuatu (Johannes 1998a, Johannes 2002, Vierros et al. 2010). In many cases TEK and SMK have combined to create effective hybrid management systems (Tawake et al. 2001, Johannes and Hickey 2004, Drew 2005, Cinner and Aswani 2007, Vierros et al. 2010).

Although there have been numerous studies investigating the nature of customary management of small-scale tropical fisheries (e.g., Aswani 1999, Cinner et al. 2005, Drew 2005, Hickey 2007, Foale et al. 2010), and the revival of traditional practices such as no-take zones (e.g., Foale and Manele 2004, Granek and Brown 2005, Aswani et al. 2007, Cinner and Aswani 2007, Cinner et al. 2007), there have been few attempts to explicitly identify the factors influencing TEK application and integration with SMK. In the case of developing Melanesian and other Pacific nations, Johannes (1998b, 2002) and Johannes et al. (2000) have suggested that catalysts for knowledge integration include the depletion of fishery stocks, limited SMK and government capacity to respond to these declines, and community ownership of marine resources based on recognized marine tenure.

More generally in fisheries management it is accepted that for the process of knowledge integration to occur, comanagement processes and forums must first develop that allow community fishers to share power with government agencies, and that also provide the enabling conditions for communication, social networking, and conflict resolution (Carlsson and Berkes 2005, Pomeroy and Rivera-Guieb 2005, Wilson et al. 2006, McConney et al. 2007, Pomeroy 2007, Kuperan et al. 2008, Pinkerton 2009). This is particularly important because tensions can emerge on account of the rationalist tendency of science to test, validate, and hence subjugate TEK, while Indigenous groups show reciprocal mistrust of SMK (Moller et al. 2004, Foale 2006, Carter and Hill 2007, Gratani et al. 2011). This tension is often exacerbated by different modes of communication and asymmetrical power relations among stakeholders (Davidson-Hunt 2006, Wilson et al. 2006, Doubleday 2007, Nadasdy 2007, Pinkerton 2009). However, if the comanagement process can evolve further to include iterative colearning and knowledge generation through experimentation, the resulting 'adaptive comanagement' can enhance the resilience of social-ecological systems to change by building adaptive capacity (Olsson et al. 2004, Folke et al. 2005, Plummer and Armitage 2007a, 2007b, Armitage et al. 2009, Plummer 2009).

Garibaldi and Turner (2004) have suggested that "cultural keystone species" may facilitate linkages between TEK and SMK. They define such animals or plants as "culturally salient species that shape in a major way the cultural identity of a people" (Garibaldi and Turner 2004:4). Further, "the detailed traditional ecological knowledge surrounding such species can bring to ecologists and conservation biologists a better appreciation of and respect for traditional knowledge systems in general, and can serve as a window through which such understandings are realized" (Garibaldi and Turner 2004:14). The application of TEK in the management of cultural keystone species can be closely tied to the expression and revival of traditional indigenous culture and marine resourceuse rights. Examples include the Haida people and Pacific herring in British Columbia (Jones 2007, Jones et al. 2010), the Ho' olehua Homestead and whitesaddle goatfish in Hawai' $i$ (Poepoe et al. 2007), and Nunavat communities and narwhal in Arctic Canada (Armitage 2005a, 2007).

The Torres Strait Islands form the Australian border with Papua New Guinea (PNG). Since European colonization in the 1870s the region has undergone rapid social and ecological change, with the introduction of Christianity, colonial rule, and the early development of commercial inshore fisheries (Johannes and MacFarlane 1991). The largely Melanesian culture became subsumed by Australian government and law, suppressing customary land and sea tenures, which has contributed to Torres Strait islanders' socioeconomic disadvantage (Smyth et al. 2006, Mulrennan 2007). Although the Torres Strait's diverse fisheries are recognized as the primary resource underpinning potential economic development for islanders (TSRA 2009), the status of many exploited populations is uncertain (PZJA 2008, Wilson et al. 2009). Concurrently there is a growing motivation among islanders to regain sovereignty over marine resources (Scott and Mulrennan 1999, Mulrennan and Scott 2000), expressed through a Regional Sea Claim lodged in 2001 (Mulrennan and Scott 2001), restoration of traditional culture, locally known as 'Ailan Kastom' (TSRA 2005, 2009), and involvement in the management of commercial fisheries (Mulrennan 2007), environmental research, and monitoring (Jones et al. 2008, Mellors et al. 2008).

Set within Melanesia where TEK has been applied to generate innovative and more effective fisheries management, the Torres Strait is a contrasting situation of a minority indigenous culture within a developed economy. In this paper we investigate the current characteristics of TEK application in fisheries management and research in the Torres Strait, and compare them with those found in other knowledge integration processes documented in neighboring areas of Melanesia and other contexts. From our analysis we conclude that TEK application in the Torres Strait is at an early stage, and is being driven by cultural keystone species that have catalyzed comanagement, precipitating similar processes for other fishery species of lesser cultural importance. We discuss how knowledge integration could be advanced through adaptive comanagement to improve fisheries management and enhance the resilience of the Torres Strait and similar social-ecological systems. 


\section{THE TORRES STRAIT}

\section{Geography and history}

The Torres Strait contains more than 150 small islands in the shallow $165 \mathrm{~km}$ stretch of water lying between the state of Queensland, Australia, and Western Province, PNG (Fig. 1). Today 15 islands are permanently inhabited with a total population of approximately 7000 people (TSRA 2005). The earliest settlers were Melanesians who arrived 3000-2500 years Before Present (Barham 2000).

Fig. 1. The Torres Strait, showing the Torres Strait Protected Zone (TSPZ) established under the Torres Strait Treaty and the location of Australian and Papua New Guinea communities.

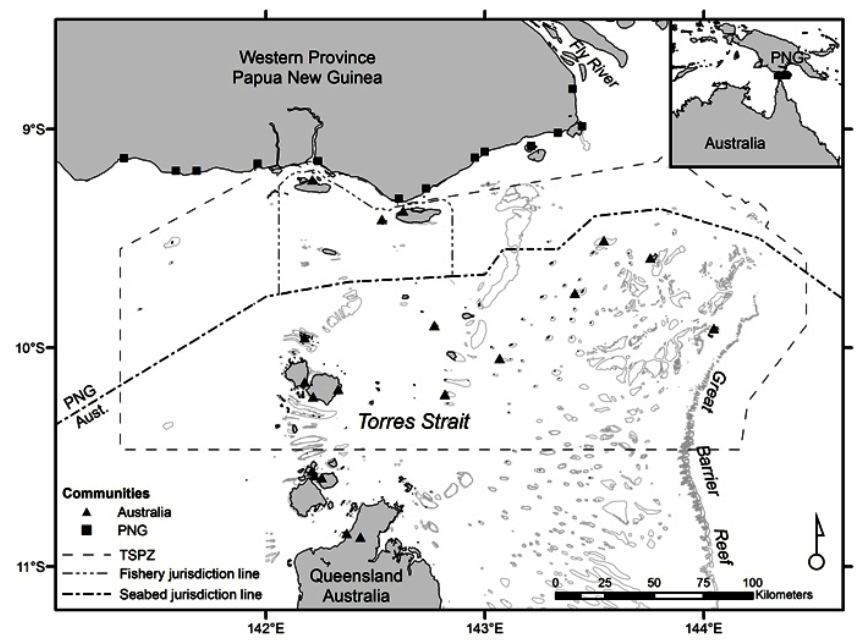

Complex social relationships exist between Torres Strait and neighboring PNG communities (Figure 1 in Beckett 1987). These have been recognized by the Torres Strait Treaty ('the Treaty'), signed between Australia and PNG in 1985 to establish a shared Protected Zone (PZ), the principal purpose of which is to "protect the traditional way of life and livelihoods of the traditional inhabitants of the Torres Strait and adjacent coastal areas of the two countries" (PZJA 2008:5).

\section{TEK in the Torres Strait}

The intricate connection of Torres Strait islanders to the marine environment is expressed in the diversity of languages, mythologies, ceremonies, and customary tenure systems that form Ailan Kastom (Mulrennan and Scott 2000, 2001, McNiven and Feldman 2003). This relationship is exemplified by estimates that the islanders have one of the highest rates of seafood consumption per capita in the world, based on the exploitation of at least 350 species (Johannes and MacFarlane 1991, Harris et al. 1994, McNiven and Hitchcock 2004).
Johannes and MacFarlane (1991) conducted a survey of the traditional fisheries of the Torres Strait, and provided evidence that, although eroded by a century of colonization, some TEK of marine resources remained. Examples included knowledge of green turtle (Chelonia mydas) and dugong (Dugong dugon) behavior, physiology, and interannual variations in abundance, traditional fishing technology such as fish drives and poisons, and complex customary marine tenure and access arrangements for reefs, inhabited, and uninhabited islands. This mirrored anthropological studies by Nietschmann (1984, 1989), Sharpe (1992), and Cordell (1995), which also identified widespread and extant cultural practices related to marine resources such as seasonal calendars, totemic associations, and gender-specific norms and superstitions.

However, there has been little systematic documentation of TEK across the Torres Strait. Smyth et al. (2006) classified the cultural values of marine species according to cultural domains (Table 1), but only recently has a TEK project been established to archive remaining cultural and historical information for each island (MacLaren 2012).

Table 1. Smyth et al.'s (2006) nine cultural domains and elements applied to classify the cultural value of Torres Strait marine species.

\begin{tabular}{ll}
\hline \hline Cultural domain & Cultural elements \\
\hline $\begin{array}{l}\text { 1. Subsistence food } \\
\text { source }\end{array}$ & $\begin{array}{l}\text { Dietary preferences, desired, required (consumed } \\
\text { and not consumed) }\end{array}$ \\
2. Material application & $\begin{array}{l}\text { Use as bait, pet, container, tool or trade item, use } \\
\text { of feathers, shell, bone, tooth, skin for } \\
\text { ornamentation, body jewelry, masks, dancing } \\
\text { paraphernalia, head gear, fish traps, sacred sites }\end{array}$
\end{tabular}

3. Subsistence skills Procurement, preparation, exchange and trade, e. g., hunting, fishing, collecting techniques, butchering, distribution, cooking, presentation

4. Wisdom Environmental knowledge about behavior, habitat, place locality, season, moon phase, tide, current, wind

5. Socio-political Totem and identity, e.g., connected to social representation groups, clans, and tribes; naming of cultural sites, e.g., seascape and territory

6. Mythological Story, myth, legend, folktale representation

7. Ritual representation Ceremony, ritual, magic, beliefs

8. Symbolic Constellations, rock art, music, song, story, representation dance, technical arts

9. Contemporary Utilization by institutions, e.g., fisheries, Torres representation Strait Treaty, schools, teams; politics, e.g., flags; commercial utilization 
Fig. 2. The Torres Strait Protected Zone Joint Authority (PZJA) consultative committee framework, stakeholder groups, and their voting representatives' numbers (summarized from PZJA 2008). Abbreviations are: Australian Fisheries Management Authority (AFMA), Torres Strait Regional Authority (TSRA), Queensland Fisheries (QF), TSRA Community Fisher Group (CFG), Department of Environment, Water, Heritage and the Arts (DEWHA), Department of Foreign Affairs and Trade (DFAT), Australian Bureau of Agricultural and Resource Economics (ABARE), Great Barrier Reef Marine Park Authority (GBRMPA), Papua New Guinea National Fisheries Authority (PNG NFA).

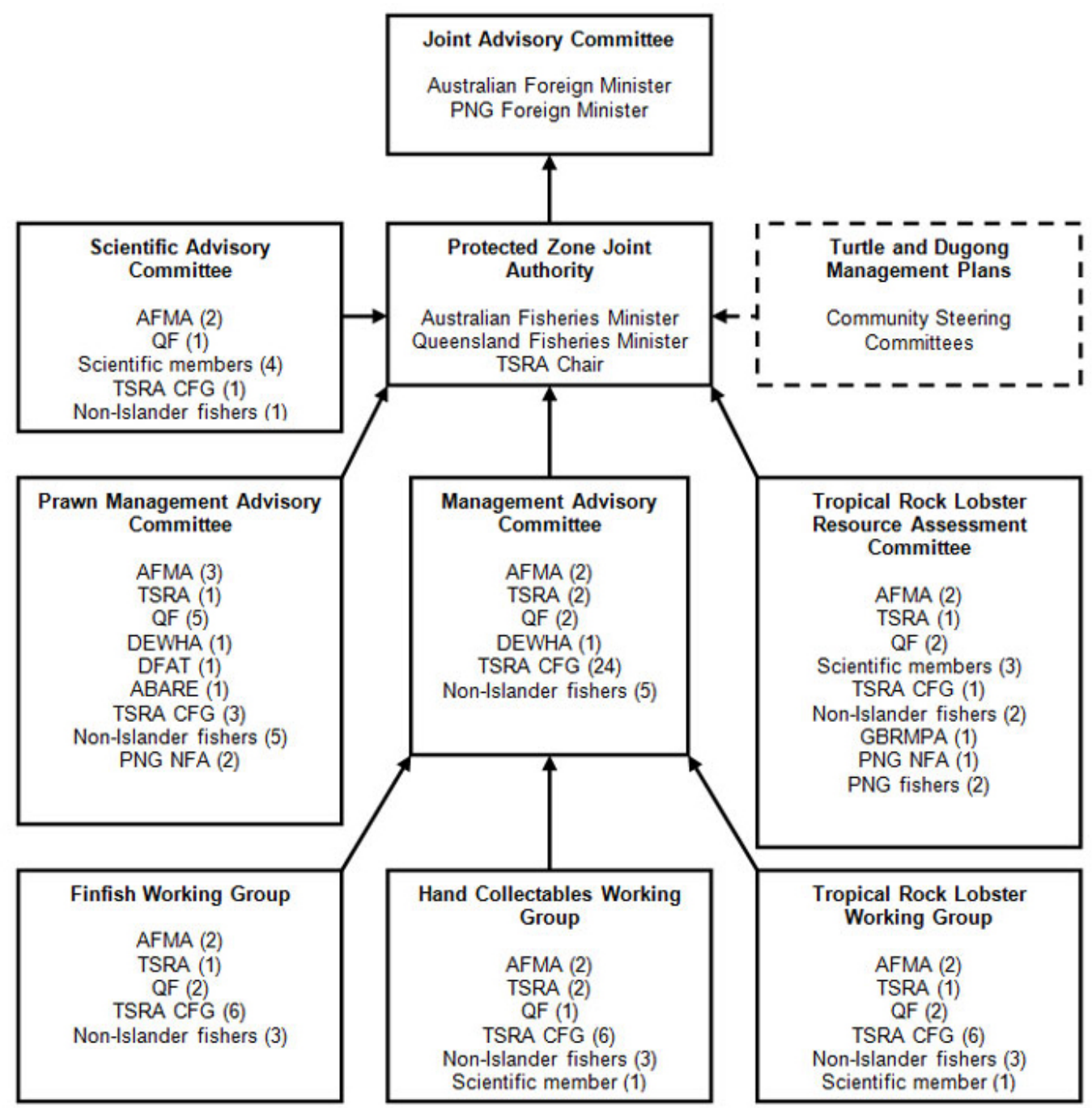

\section{Fisheries management}

The Torres Strait Protected Zone Joint Authority (PZJA) was established in 1984 under the Torres Strait Fisheries Act. Its purpose is to manage the interests of Australian fisheries in the PZ. The PZJA reports to the Treaty's Joint Advisory Council, which is governed by the Foreign Ministers of Australia and PNG. It consists of the Australian and Queensland state governments' Fisheries Ministers and the Chair of the Torres Strait Regional Authority (TSRA), a Torres Strait islander-led Australian Government statutory authority. It is advised by a system of consultative committees that include government fisheries managers and scientists, plus PNG government representatives for shared fisheries (Fig. 2). In 2002 the TSRA established a Community Fisher Group (CFG) that selects active fishers from island communities to represent their interests on the committees.

Under the Act all fisheries are required to prepare a management plan. They must also periodically undergo a strategic assessment under the Australian Environment Protection Biodiversity Conservation (EPBC) Act of 1999 to evaluate their impact on protected species, and devise mitigating actions. 


\section{Commercial fisheries and stocks}

The following commercial fisheries are formally recognized in the PZ: prawns, tropical rock lobster (Panulirus ornatus), finfish (mackerel, coral trout [Plectropomus leopardus], barramundi [Lates calcarifer], and mixed reef fish), hand collectables (bêche-de-mer, trochus, and pearl shell), and crabs. Science-based stock assessments are undertaken for some individual species, and fishery-specific management tools such as licensing, temporal and gear restrictions are applied to control fishing effort (PZJA 2008). Stock assessments indicate that bêche-de-mer and pearl shell are overfished, whereas the status of five other species is uncertain, and five are not overfished.

\section{Traditional fisheries and stocks}

Traditional fisheries include unlicensed fishing for subsistence or cultural use, and also fall under the PZJA's aegis, although formal committees do not exist for them (PZJA 2008). Under the Treaty three fisheries are recognized:

\section{Dugong}

Hunting dugong is an integral part of Ailan Kastom, and is a major source of protein in the western islands (Johannes and MacFarlane 1991, Skewes et al. 2002, Kwan et al. 2006). Hunting is a skilled male activity and is usually carried out using a spear thrown from a dinghy. The distribution of meat maintains a tradition of reciprocity and respect among communities (Kwan et al. 2001, 2006). Nietschmann (1989) suggests that hunting has persisted because it preserves a way of life and body of knowledge that gives meaning to islander's livelihoods, and sets the context for cultural history and environmental knowledge. The dugong is listed as threatened under the EPBC Act, vulnerable to extinction by the IUCN, and is on Appendix II of the Convention on International Trade in Endangered Species of Wild Fauna and Flora. The Torres Strait is one of the most important remaining dugong habitats in the world (Marsh et al. 2002) with an estimated population of 15,000 in 2006 (PZJA 2008). There is concern among scientists that the catch of dugong is unsustainable (Heinsohn et al. 2004, Marsh et al. 2004), but there is disagreement between scientists and islanders about the size of the population, partly due to large interannual fluctuations in numbers driven by changes in seagrass abundance (Johannes and Neis 2007). This, combined with a lack of accurate catch data from Australian and PNG communities makes assessments of the population's status uncertain (PZJA 2008).

\section{Turtle}

Green turtles are the primary target species for traditional harvest, although the eggs of hawksbill (Eretmochelys imbricata) and flatback (Chelonia depressa) turtles are also taken. As for dugong, all three species have a high conservation status under national and international schedules. The hunting of green turtles is an important facet of Ailan Kastom, and also contributes significantly to islander diet (Kwan et al. 2001).
There is considerable uncertainty in catch data (Skewes et al. 2002), and censuses of nesting green turtles from beaches in the region indicate that the average size is declining, potentially due to overharvesting (Limpus 2008). Monitoring of nesting female hawksbill turtles has shown a steady decline in their numbers in 1976-2009 (Limpus 2009).

\section{Reef fishery}

This category includes all other subsistence gathering of fish and invertebrates. Although stocks of commercial species also taken for subsistence are formally assessed by the PZJA, noncommercial species are not.

\section{Comanagement of fisheries}

Comanagement is not explicitly mentioned by any government publications relating to Torres Strait fisheries management. However, it is clear that comanagement processes have been evolving since the signing of the Treaty in 1985, and are most evident in four Torres Strait fisheries: turtle, dugong, lobster, and hand collectables. We summarize these processes chronologically, and then analyze this information through a comanagement conceptual framework.

\section{Turtle and dugong}

Because of their importance to islanders' livelihoods, their protected and endangered status under national and international legislation, and concern about the impacts of over-harvesting for both islanders' and broader conservation interests, turtles and dugong have been a combined focus for comanagement. Kwan et al. (2001) and NAILSMA (2005) provide a history of key steps in this process. In 1985 the PZJA established a dugong sanctuary in the western Torres Strait, where hunting is prohibited. In 1995 a ban was placed on hunting dugong by any methods other than the traditional spear. These decisions involved minimal community participation, but the consultative development of a Torres Strait Marine Strategy by the TSRA in the early 1990s more fully engaged and empowered islanders, and turtle and dugong fisheries became a focus of attention. In 1997 the PZJA recommended that a community-based management strategy should be developed to ensure that the turtle and dugong harvest was sustainable, instigating an Australian Fisheries Management Authority (AFMA) workshop in June 1998 at which islander leaders, hunters, and government agencies agreed that future management required the integration of SMK with islander perspectives on sustaining turtle and dugong populations. The jointly agreed vision from the workshop was to achieve "effective community based management of dugongs and turtles conducted in a way that maintains Ailan Kastom and ensures the long term survival of these species as an essential component of Torres Strait culture, identity, and sea life" (Kwan et al. 2001:226).

These stakeholders then jointly worked toward developing Turtle and Dugong Management Plans (TDMPs) for individual islands. This process culminated in the 
implementation of eight plans in 2008, which have the objective of achieving sustainable harvesting while reviving TEK, and integrating this with SMK. Each plan aims to meet the requirements of an assessment for the EPBC Act, and the development of a management plan, while maintaining islanders' control over decisions. Actions to be implemented by each plan include a hunting permit system and seasonal closures over an agreed area of customary sea tenure, catch monitoring, and traditional hunting and butchering methods. Government-funded Land and Sea Rangers have been employed from the island communities to facilitate the plans' implementation. Governance of each plan is undertaken by a steering committee consisting of community leaders and hunters. It has been proposed that a Turtle and Dugong Working Group (WG) should be formed to achieve regional coordination of plans and engage with the PZJA (Fig. 2). In spite of this progress, using a social network analysis, Weiss et al. (2012) suggest that the comanagement process is still dominated by top-down government influence.

\section{Tropical rock lobster}

The first steps toward comanagement of the lobster fishery were taken in 2001, when islander concerns about the status of lobster stocks resulted in a ban on the use of hookah diving gear and an increase in the minimum takeable size (Mulrennan 2007). This was a watershed because for the first time the PZJA held an open forum with islanders invited to attend as observers; prior to this, islander input had been limited (Mulrennan and Scott 2005). In 2002 the PZJA structure was modified to include CFG members in the lobster fishery committees. However, genuine power-sharing and joint decision making was not immediately apparent, and power asymmetries remained (Mulrennan and Scott 2005, Mulrennan 2007). Unresolved tensions were still evident between islander and nonislander fishermen and government representatives during the 2004 process to buy back nonislander fishing licenses and the substitution of total allowable catches with an individual transferable quota system in 2005 (van Putten et al. 2012).

\section{Hand collectables}

In 1993 the fishery for the most valuable bêche-de-mer species, sandfish (Holothuria scabra), was closed by the PZJA because stock assessments indicated overfishing. Following further assessments the fishery was reopened in 1995, but then closed again in 1998. In 2004 a strategic assessment of the bêche-de-mer fishery under the EPBC Act recommended the development of community-designed harvest strategies in preparation for the reopening of the sandfish fishery, and the formation of a Hand Collectables WG to facilitate community involvement in monitoring and management (PZJA 2004). In 2005 a multistakeholder Torres Strait Cooperative Research Centre (CRC) workshop was held to discuss these recommendations, entitled 'Bêche-de-mer Sustainability: a Collaborative Approach' (PZJA 2005). This was followed in
2007 by the inaugural WG meeting consisting of an islander chairperson and six CFG members among eight nonislander members (Fig. 2). The WG acted on the development of islandspecific management plans and harvest strategies that would prevent future overfishing, incorporate TEK, and involve islanders in research to build their trust in stock assessments (PZJA 2007). The potential involvement of the rangers in community-based management of hand collectables was also explored (PZJA 2007). By 2009 the WG had facilitated prototype community-based harvest strategies on two islands that restore traditional spatial management systems (J. R. A. Butler, A. Tawake, T. Skewes, L. Tawake, and V. McGrath, unpublished manuscript).

Comanagement processes are less evident in the remaining fisheries, although there has been some community involvement in management. For example, islanders submit catch records in the commercial finfish fishery (Williams et al. 2008), and there have been unsuccessful attempts to establish community-based catch monitoring for the traditional reef fishery (Harris et al. 1994, Skewes et al. 2002, Busilacchi 2008).

\section{METHODS}

\section{Application of TEK}

To assess the current application of TEK in fisheries management, we distributed a self-completion questionnaire survey in 2009 to the 23 managers and scientists from the Australian government departments and agencies responsible for managing and assessing commercial and traditional fisheries. Following guidelines for questionnaire design (de Vaus 2002) seven open-ended questions were presented:

1. How do you define TEK?

2. Have islanders been involved in fisheries monitoring and research?

3. If yes, how?

4. Is any TEK applied in the management, monitoring, and research of the fishery species?

5. If yes, what form of knowledge and how is it applied?

6. If not, why not?

7. When did the application of TEK begin?

\section{Factors influencing TEK application}

We assessed three sets of factors that potentially explained the characteristics of TEK application observed from the survey:

Stock depletion, limited SMK, and community ownership Johannes (1998a, 2002) and Johannes et al. (2000) suggested that in other regions of Melanesia and the Pacific, the depletion of fishery stocks, limited SMK to respond to these declines, and community ownership of resources were important 
factors. We evaluated each fishery in these terms as follows: (1) Stock collapse: We categorized each fishery's stock status in 2009 as overfished, uncertain, or not overfished from PZJA (2008) and Wilson et al. (2009); (2) Limited SMK: Tawake et al. (2010) compiled all available stock assessment data and categorized current SMK of fisheries into four classes. We applied a SMK rank to each:

- High: at least one stock assessment in 2004-2008 with high data confidence $(\mathrm{SMK}=1)$;

- Medium: at least one stock assessment in 2004-2008 with uncertain data confidence $(\mathrm{SMK}=2)$;

- Low: no stock assessment but some catch data collected in 2004-2008 with uncertain data confidence (SMK = 3);

- None: no catch or other data collected in 2004-2008 $(\mathrm{SMK}=4)$.

(3) Community ownership: As a surrogate for resource ownership we collated data from PZJA (2008) and Wilson et al. (2009) on the proportion of commercial fishing licenses held by islanders. Traditional fisheries are only operated by islanders and therefore were considered totally owned by them.

Following the inference of Johannes (1998a, 2002) and Johannes et al. (2000) for Melanesia, we defined the criteria where application of TEK was most likely to occur as being overfished or uncertain stock status, low or none SMK, and > 60\% ownership (Fig. 3). Where data allowed we presented results for individual species, and aggregated them into groups when this was not possible.

\section{Comanagement characteristics}

Comanagement processes and the degree of power-sharing among stakeholders are known to be influential in knowledge integration in fisheries management (Wilson et al. 2006, Pomeroy 2007, Pinkerton 2009). We assessed these factors in two ways: (1) Comanagement stages: Plummer (2006) identified three stages in the evolution of comanagement. The first is termed "independence," in which interaction between the government and local actors is limited. The second is "association," in which the actors begin to interact, exchanging information and articulating resource values and a shared vision for management objectives. The third stage, "integration" involves the actors collectively undertaking a task, sharing the consequences of their actions, and resolving conflict. To analyze the evolution of comanagement in fisheries we applied Plummer's (2006) conceptual framework to identify the years when each stage was reached, and compared this to the year when TEK was first applied. (2) Power-sharing: To evaluate the extent of power-sharing between islanders and government agencies in 2009, we calculated the proportion of CFG or islander members with voting mandates among all PZJA committees relating to each
Fig. 3. Fishery species or groups for which traditional ecological knowledge (TEK) a) was applied and b) was not applied relative to fishery ownership, stock status, and science and management knowledge (SMK). The dashed line box represents the status of the species for which TEK application could occur. Abbreviations are: green turtle (Chelonia mydas; GT), hawksbill turtle (Eretmochelys imbricata; HT), flatback turtle (Chelonia depressa; FT), dugong (Dugong dugon; DUG), trochus (TRO), bêche-demer (BDM), tropical rock lobster (Panulirus ornatus; TRL), mixed finfish (MFF), invertebrates (INV), coral trout (Plectropomus leopardus; COR), barramundi (Lates calcarifer; BAR), mixed reef fish (MRF), mackerel (MAC), blue endeavour prawns (Metapenaeus endeavouri; END), brown tiger prawns (Penaeus esculentus; TIG), and redspot king prawns (Melicertus longistylus; RED). Note that for ease of presentation, symbols have been separated where more than one species had the same stock status, e.g., GT, HT, DUG, and ownership (\%) values have been categorized into intervals of $20 \%$ from data in Table 1.
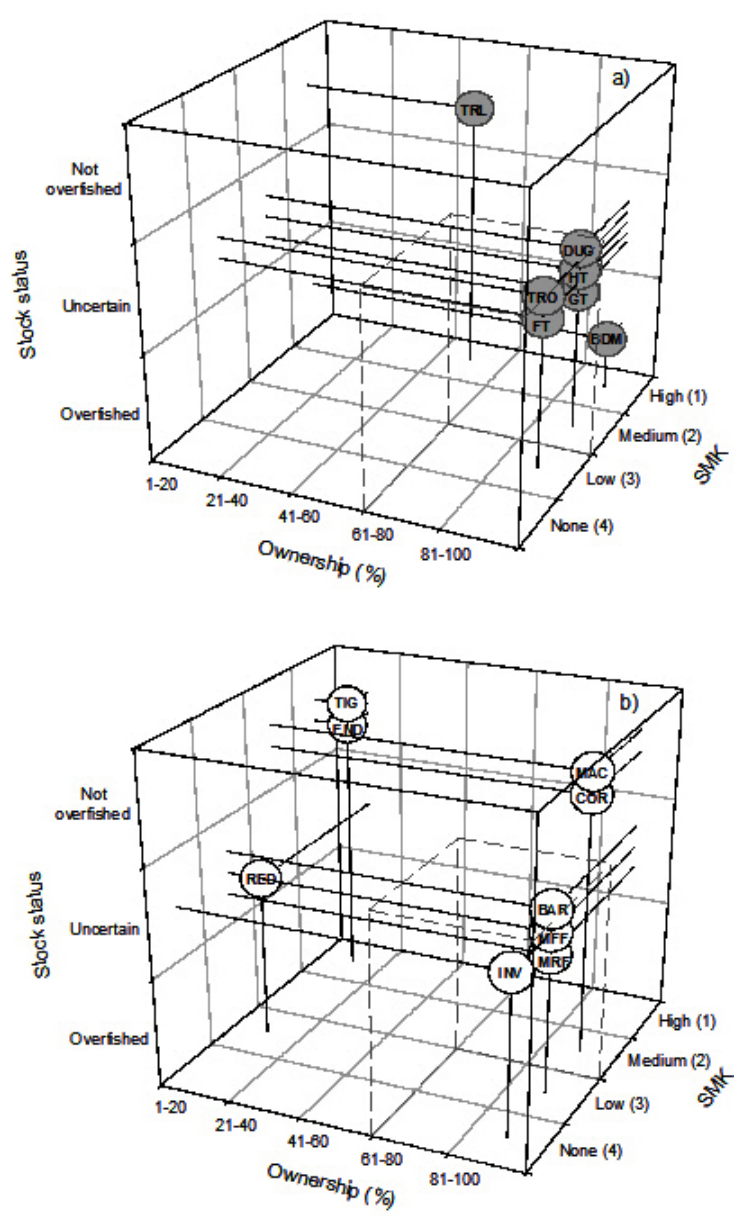
Table 2. Fisheries for which traditional ecological knowledge (TEK) has and has not been applied in the Torres Strait, and the details of TEK applied.

\begin{tabular}{|c|c|c|c|}
\hline \multirow[b]{2}{*}{ Fishery } & \multicolumn{2}{|c|}{ Application of TEK } & \multirow[b]{2}{*}{ Start year } \\
\hline & Islander involvement in monitoring and research & TEK applied/reason not applied & \\
\hline \multicolumn{4}{|l|}{ TEK Applied: } \\
\hline Turtle & $\begin{array}{l}\text { Monitoring catches, nesting beaches, tissue sampling } \\
\text { carcasses, tagging by hunters and rangers }\end{array}$ & $\begin{array}{l}\text { Knowledge of nesting beaches, distribution, } \\
\text { sexing of adults, and capture methods for } \\
\text { research }\end{array}$ & 2006 \\
\hline Dugong (Dugong dugon) & $\begin{array}{l}\text { Monitoring catches, tissue sampling carcasses by hunters } \\
\text { and rangers }\end{array}$ & $\begin{array}{l}\text { Seasonal movements, hunting methods, and } \\
\text { catch utilization }\end{array}$ & 2006 \\
\hline $\begin{array}{l}\text { Tropical rock lobster } \\
\text { (Panulirus ornatus) }\end{array}$ & Catch recording & $\begin{array}{l}\text { Knowledge of lobster distribution in shallow } \\
\text { waters near islands }\end{array}$ & 2008 \\
\hline Hand collectables & $\begin{array}{l}\text { Four trainees in } 2009 \text { bêche-de-mer and trochus survey, } \\
\text { catch recording }\end{array}$ & $\begin{array}{l}\text { Identification of bêche-de-mer and trochus } \\
\text { habitat for survey }\end{array}$ & 2009 \\
\hline \multicolumn{4}{|l|}{ TEK Not Applied: } \\
\hline Reef fishery & Catch surveys & Not relevant & \\
\hline Finfish & Catch recoding & Not appropriate & \\
\hline Prawn & None & Islanders are not involved in the fishery & \\
\hline
\end{tabular}

fishery. Data for commercial fisheries were taken from PZJA (2008), and those for TDMPs were provided by the TSRA (see Fig. 2). We compared these data to the application of TEK in each fishery.

\section{Cultural values of species}

Garibaldi and Turner (2004) proposed that cultural keystone species may facilitate linkages between TEK and SMK. To assess the relative cultural importance of fishery species to islanders we applied Smyth et al.'s (2006) study of the cultural values of marine species in the Torres Strait. They classified species into one or more of nine cultural domains, with each domain containing culturally constructed elements and values (Table 1). We summed the number of domains recorded by Smyth et al. (2006) for each species to yield a cultural value (CV) score.

We statistically compared the mean CV score for those species for which TEK had been applied versus those for which it had not using a T-test. We then compared the CV score of species and fisheries with the stage of comanagement reached in the respective fisheries in 2009.

\section{RESULTS}

\section{Application of TEK}

Thirteen questionnaires were returned (57\% response rate). Responses were received from managers or scientists for all fisheries except crabs and pearl shell.

TEK had been applied in four fisheries: turtle, dugong, lobster, and hand collectables, i.e., bêche-de-mer and trochus (Table 2 ). The most extensive application was evident in turtle and dugong fisheries, and began in 2006. Since 2008 TEK application for these fisheries has been implemented through the rangers' involvement in monitoring and research. By comparison TEK applied to lobster, trochus, and bêche-demer began more recently through the engagement of four islander trainees in the 2009 stock assessment surveys of trochus and bêche-de-mer, and lobster surveys in 2008. In all cases the TEK concerned consisted of behavioral and physiological information about animals and their distribution, and for turtle and dugong also traditional capture and carcass handling techniques.

TEK was not applied in the traditional reef fishery, the commercial finfish, or prawn fisheries. All respondents' reasons were 'not relevant,' 'not appropriate,' or 'islanders not involved in the fishery,' respectively.

\section{Factors influencing TEK application}

Stock depletion, limited SMK, and community ownership Among the seven species or groups for which TEK had been applied, the characteristics of only two, i.e., flatback turtle and trochus, had uncertain stock status, low SMK, and total ownership of the fisheries (Fig. 3a, Table 3). The lack of TEK application in the management of barramundi, mixed reef fish, mixed finfish, and invertebrates was unexpected, because according to the criteria suggested by Johannes $(1998 a, 2002)$ and Johannes et al. (2000), TEK should have been applied in these fisheries because of their uncertain stock status, low SMK, and high islander ownership (see Fig. 3b).

\section{Comanagement characteristics}

The comanagement process was most advanced for turtle and dugong relative to other fisheries. The association stage began in 1998 with the AFMA workshop, when islanders and government agencies agreed to a common vision for achieving sustainable turtle and dugong populations (Fig. 4). Integration began with the implementation of the TDMPs and the employment of rangers in 2008.

Association began for the lobster fishery in 2001, when islander concerns about overfishing resulted in more stringent controls (Fig. 4). This was progressed in 2002 when the PZJA 
Table 3. Stock status, science and management knowledge (SMK), and cultural value (CV) scores for commercial and traditional fisheries and species in the Torres Strait.

\begin{tabular}{|c|c|c|c|c|c|}
\hline \multirow[b]{2}{*}{ Fishery and species } & \multirow[b]{2}{*}{ Stock status ${ }^{\dagger}$} & \multirow[b]{2}{*}{$\mathrm{SMK}^{+}$} & \multirow[b]{2}{*}{ Islander ownership } & \multicolumn{2}{|c|}{ CV score } \\
\hline & & & & Fishery average & Species \\
\hline \multicolumn{6}{|l|}{ Commercial Fishery } \\
\hline Prawn & & & None & 1.0 & \\
\hline $\begin{array}{l}\text { Blue endeavour (Metapenaeus } \\
\text { endeavouri) }\end{array}$ & Not overfished & 1 & & & 1 \\
\hline $\begin{array}{l}\text { Brown tiger (Penaeus } \\
\text { esculentus) }\end{array}$ & Not overfished & 1 & & & 1 \\
\hline $\begin{array}{l}\text { Redspot king (Melicertus } \\
\text { longistylus) }\end{array}$ & Uncertain & 3 & & & 1 \\
\hline $\begin{array}{l}\text { Tropical rock lobster } \\
\text { (Panulirus ornatus) }\end{array}$ & Not overfished & 1 & $54 \%$ of licenses & 8 & 8 \\
\hline Finfish & & & $98 \%$ of licenses & 1.8 & \\
\hline Mackerel & Not overfished & 2 & & & $2.0^{\S}$ \\
\hline $\begin{array}{l}\text { Coral trout (Plectropomus } \\
\text { leopardus) }\end{array}$ & Not overfished & 2 & & & 1 \\
\hline Barramundi (Lates calcarifer) & Uncertain & 3 & & & 1 \\
\hline Mixed reef fish ${ }^{\prime}$ & Uncertain & 3 & & & $1.9^{\mathbb{I I}}$ \\
\hline Hand collectables & & & $99 \%$ of licenses & 5.8 & \\
\hline Bêche-de-mer & Overfished & 1 & & & $3^{\#}$ \\
\hline Trochus & Uncertain & 3 & & & $7.0^{\dagger \dagger}$ \\
\hline Pearl shell & Overfished & 3 & & & $6.0^{\text {辛 }}$ \\
\hline Crab & Uncertain & 3 & $100 \%$ of licenses & 5.5 & $5.5^{\S \S}$ \\
\hline \multicolumn{6}{|l|}{ Traditional Fishery } \\
\hline Turtle & & & $100 \%$ & 6.3 & \\
\hline Green turtle (Chelonia mydas) & Uncertain & 2 & & & 9 \\
\hline $\begin{array}{l}\text { Hawksbill turtle (Eretmochelys } \\
\text { imbricata) }\end{array}$ & Uncertain & 2 & & & 9 \\
\hline $\begin{array}{l}\text { Flatback turtle (Chelonia } \\
\text { depressa) }\end{array}$ & Uncertain & 3 & & & 1 \\
\hline Dugong (Dugong dugon) & Uncertain & 2 & $100 \%$ & & 9 \\
\hline Reef fishery & & & $100 \%$ & 3.0 & \\
\hline Mixed finfish & Uncertain & 3 & & & $1.8^{\|}$ \\
\hline Invertebrates & Uncertain & 4 & & & $4.3^{\text {IIII }}$ \\
\hline
\end{tabular}

${ }^{\dagger}$ Derived from PZJA (2008) or Wilson et al. (2009).

$¥ 1$ = high, 2 = medium, 3 = low, 4 = none.

$\S$ Three species combined by Smyth et al. (2006): Spanish (Scomberomorus commerson), school (S. queenslandicus), and shark mackerel (Grammatorcynus bicarinatus).

I Snappers, emperors (Lutjanus and Lethrinus spp.), and rock cods (Epinephelus spp.).

${ }^{\mathbb{I I}}$ Average for 16 species of snappers, emperors, and rock cods from Smyth et al. (2006).

\# 14 species combined by Smyth et al. (2006).

${ }^{\dagger}$ Average for two species from Smyth et al. (2006): Trochus niloticus and T. cerithium.

Average for two species from Smyth et al. (2006): black-lipped (Pinctada margaritifera) and golden-lipped pearl shell (P. maxima).

$\$$ Average for two species from Smyth et al. (2006): mud (Scylla serata) and blue swimmer crabs (Portunus pelagicus).

" Average for 22 species from Smyth et al. (2006), excluding commercial finfish species.

IIII Average for 19 species of gastropods, bivalves, squid, and octopus from Smyth et al. (2006).

consultative structure was modified to include CFG members. However, the incomplete and contested license buy-back process suggests that the integration stage has not yet been reached. For hand collectables the association stage was instigated by the 2005 CRC workshop, which explored a collaborative approach to the future management of bêche-de- mer, followed by the establishment of the Hand Collectables WG in 2007 and the development of community-based harvest strategies (Fig. 4).

TEK was only applied in these four fisheries, and its first application occurred several years after the association stage 
Fig. 4. The chronology of comanagement and application of traditional ecological knowledge (TEK) in the turtle and dugong (Dugong dugon), lobster and hand collectable fisheries between the 1985 signing of the Torres Strait Treaty and 2009, applying Plummer's (2006) stages of 'independence,' 'association,' and 'integration.' Abbreviations are: Protected Zone Joint Authority (PZJA), Australian Fisheries Management Authority (AFMA), Turtle and Dugong Management Plan (TDMP), Community Fisher Group (CFG), Working Group (WG), Management Advisory Committee (MAC), Scientific Advisory Committee (SAC), Cooperative Research Centre (CRC).
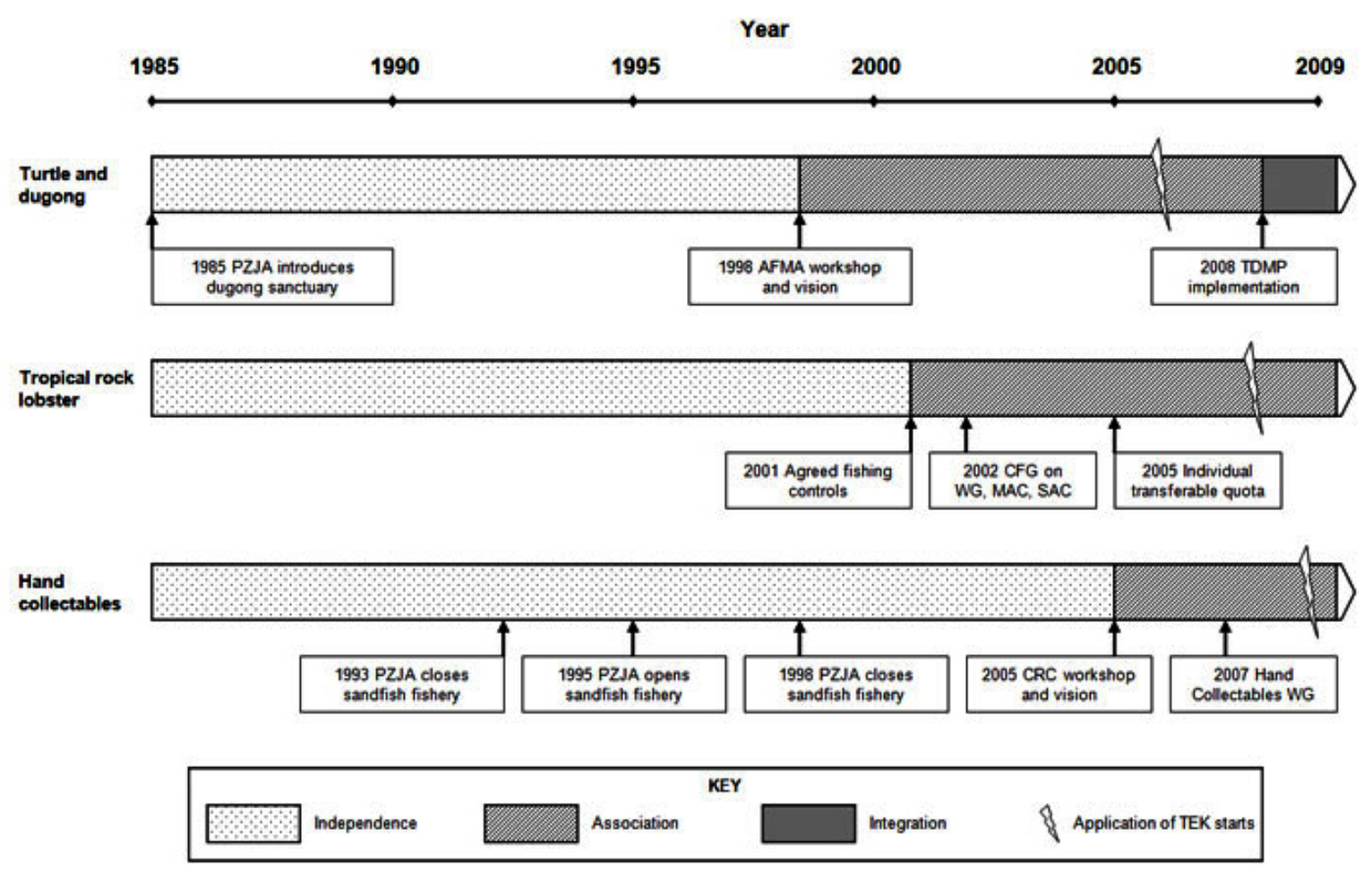

had begun (Fig. 4). This occurred first in 2006 for turtles and dugong, followed in 2008 by lobster and 2009 by hand collectables. In the prawn, finfish, and reef fisheries, where comanagement remains relatively undeveloped in the independence stage, there has been no application of TEK.

The degree of power-sharing in 2009 was also related to TEK application in each fishery (Table 4). Turtle and dugong fisheries had $90 \%$ islander representation and the earliest and most extensive application of TEK. Lobster and hand collectables had midrange representation, with $43 \%$ and $52 \%$, respectively, and more recent and relatively limited application of TEK. By comparison fisheries with no TEK application had low to midrange representation.

\section{Cultural values of species}

The CV scores for species varied widely, ranging from 1 (coral trout, barramundi) to 9 (dugong, green and hawksbill turtles; Table 3). The mean CV score for species for which TEK was applied $(6.6 \pm 3.3 \mathrm{SD}, \mathrm{n}=7)$ was significantly higher than for those for which it was not $(2.0 \pm 1.0 \mathrm{SD} ; \mathrm{n}=9 ; \mathrm{T}=3.59, \mathrm{P}=$ $0.011, \mathrm{DF}=6$ ).
TEK had been applied for the longest period for species with the highest $\mathrm{CV}$ scores, i.e., green turtle, hawksbill turtle, and dugong (Fig. 4). By 2009 comanagement for these species had reached the integration stage, whereas comanagement of species and groups of lesser value, i.e., lobster, trochus, and bêche-de-mer, had reached the association stage, with more recent and limited application of TEK (Fig. 5a). Species within the independence stage had relatively low CV scores and TEK had not been applied in their management. When these species and their CV scores were aggregated into fisheries (see Table 3 ) this pattern became clearer (Fig. 5b).

\section{DISCUSSION}

Torres Strait fisheries are typical of tropical inshore fisheries, being highly complex, small-scale, mixed commercial and subsistence, and with a high diversity of species exploited primarily by local fishers. In contrast to neighboring Melanesian nations, however, government fisheries management is relatively well resourced through multiple 
Fig. 5. The relationship between cultural domain (CV) scores for a) fishery species or groups and b) fisheries, the stage of comanagement reached in 2009 and the application of traditional ecological knowledge (TEK). Grey symbols are species or fisheries where TEK was applied, and white symbols are those where TEK was not applied.

Abbreviations for species in a) are: green turtle (Chelonia mydas; GT), hawksbill turtle (Eretmochelys imbricata; HT), flatback turtle (Chelonia depressa; FT), dugong (Dugong dugon; DUG), trochus (TRO), bêche-de-mer (BDM), tropical rock lobster (Panulirus ornatus; TRL), mixed finfish (MFF), invertebrates (INV), coral trout (Plectropomus leopardus; COR), barramundi (Lates calcarifer; BAR), mixed reef fish (MRF), mackerel (MAC), blue endeavour prawns, (Metapenaeus endeavouri; END), brown tiger prawns (Penaeus esculentus; TIG), and redspot king prawns (Melicertus longistylus; RED). Abbreviations for fisheries in b) are: turtle (TTL), hand collectables (HC), reef fishery (RF), prawn (PRN), and finfish (FF). Note that symbols have been separated where more than one species had the same comanagement stage and similar CV scores, e. g., END, RED, TIG.
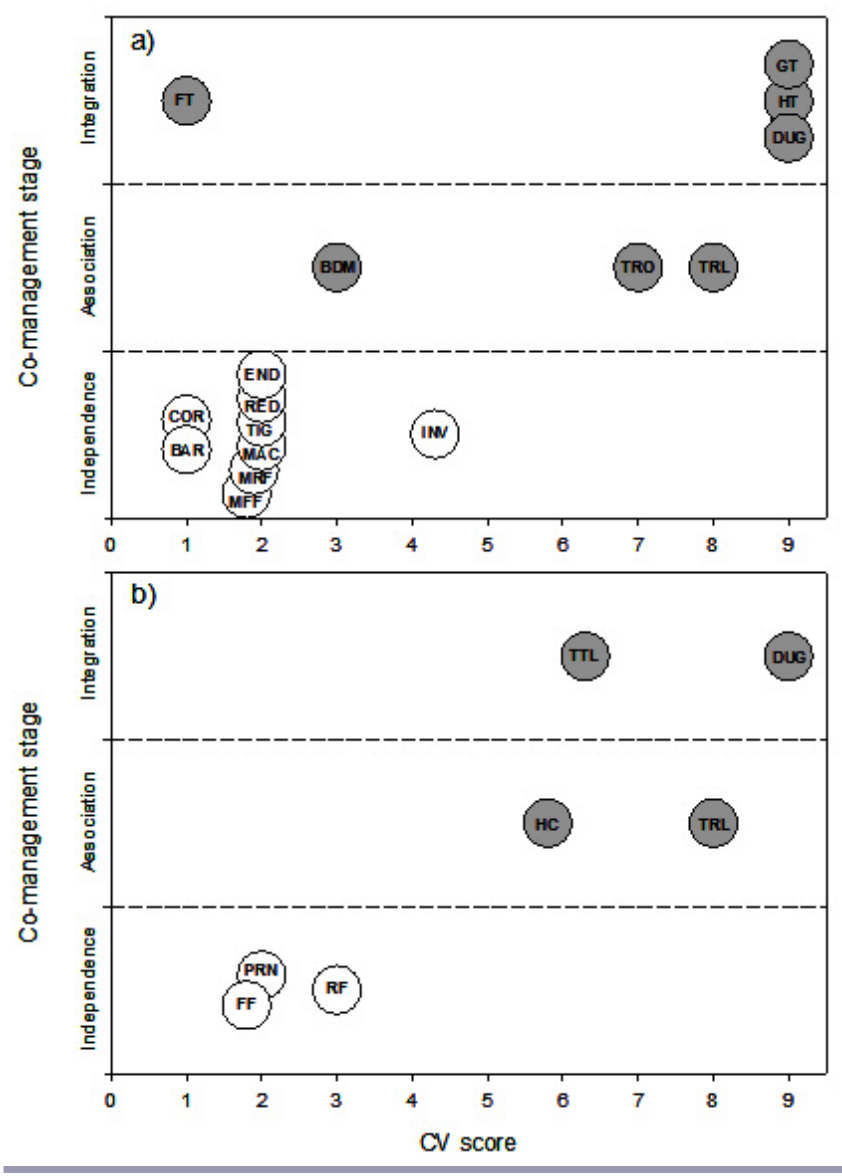

agencies, and consequently SMK of several commercial fishery species is high. However, in spite of this, the status of five commercial and all traditional species is uncertain. Hence, the challenge commonly faced by centralized, command-andcontrol governance of tropical inshore fisheries is also evident in the Torres Strait, potentially creating preconditions for islanders' TEK to be applied and integrated with SMK to generate hybrid management systems. However, our results indicate that TEK has only been recently applied in the management of four fisheries: dugong, turtles, lobsters, and hand collectables. Furthermore, this corresponded with the first level of Berkes' (1999) knowledge-practice-belief complex of TEK; that is, largely local knowledge of the species rather than management systems, institutions, and world views.

This difference was emphasized when we assessed the role of the depletion of fishery stocks, limited SMK, and community ownership of resources, which Johannes $(1998 a, 2002)$ and Johannes et al. (2000) suggested were contributory factors to the application of TEK in other Melanesian regions. Of the seven species or groups for which TEK was applied, the characteristics of only two met these criteria. Also, four other species or groups had characteristics potentially conducive to the application of TEK, yet this had not occurred.

One possible explanation for this outcome is Johannes and MacFarlane's (1991) contention that although TEK clearly still exists in the Torres Strait, it does not include a 'conservation ethic' because of the abundance of marine food resources relative to the islands' historically small human population. This contrasts with other regions of the Pacific, where higher population densities had probably depleted relatively more limited marine resources in the past, thus generating customary conservation practices and norms (Johannes 2002; but see Foale et al. 2010). Hence, overfishing of stocks in the Torres Strait might not be expected to result in the application of TEK. However, Johannes and MacFarlane's (1991) observations are contradicted by other studies in the Torres Strait. Cordell (1995) recorded strictly enforced harvest allocations for dugong, turtle, and fish, and Mulrennan (2007) argued that the commercial overfishing of pearl shell, trochus, and bêche-de-mer in the last century has led to a growing awareness and acceptance of the principle of sustainable use among islanders.

An alternative explanation is suggested by our finding that the average CV score of species for which TEK had been applied was statistically higher than for species where it had not. Our analysis suggests that the cultural value of species influenced the extent of comanagement and power-sharing, which in turn led to the application of TEK after establishment of the association stage of comanagement. However, there was also an important chronological perspective, whereby the species of highest cultural value, turtles and dugong, were the earliest focus for comanagement processes, generating significant 
Table 4. Torres Strait Regional Authority (TSRA) Community Fisher Group and/or islander representation in the Protected Zone Joint Authority (PZJA) consultative committees relative to the total number of representatives with a voting mandate on each, sorted according to the application of traditional ecological knowledge (TEK). Abbreviations are: Working Group (WG), Management Advisory Committee (MAC), Tropical Rock Lobster Resource Assessment Group (TRLRAG), Scientific Advisory Committee (SAC), and Turtle and Dugong Management Plan (TDMP).

\begin{tabular}{|c|c|c|c|c|c|c|c|c|}
\hline \multirow[b]{2}{*}{ Fishery } & \multicolumn{5}{|c|}{ PZJA consultative committees } & \multirow[b]{2}{*}{$\begin{array}{l}\text { TDMP Steering } \\
\text { Committees }\end{array}$} & \multirow[b]{2}{*}{ Total } & \multirow[b]{2}{*}{$\%$} \\
\hline & WG & MAC & Prawn MAC & TRL RAG & SAC & & & \\
\hline \multicolumn{9}{|l|}{ TEK Applied } \\
\hline Turtle & & & & & $1 / 9$ & $67 / 67$ & $68 / 76$ & 90 \\
\hline Dugong (Dugong dugon) & & & & & $1 / 9$ & $67 / 67$ & $68 / 76$ & 90 \\
\hline $\begin{array}{l}\text { Tropical rock lobster (Panulirus } \\
\text { ornatus) }\end{array}$ & $6 / 15$ & $24 / 36$ & & $1 / 15$ & $1 / 9$ & & $32 / 75$ & 43 \\
\hline Hand collectables & $6 / 15$ & $24 / 36$ & & & $1 / 9$ & & $31 / 60$ & 52 \\
\hline \multicolumn{9}{|l|}{ TEK Not Applied } \\
\hline Reef fishery & & & & & $1 / 9$ & & $1 / 9$ & 11 \\
\hline Finfish & $6 / 14$ & $24 / 36$ & & & $1 / 9$ & & $31 / 59$ & 53 \\
\hline Prawn & & & $3 / 22$ & & $1 / 9$ & & $4 / 31$ & 13 \\
\hline
\end{tabular}

islander representation and engagement in management, and hence the initial and most extensive application of TEK. Comanagement for species and fisheries of high but lesser cultural value, lobster and hand collectables, followed in succession, with later and hence more limited application of TEK.

We acknowledge that our analysis is based on a small sample size of 13 fishery managers and scientists, although this represented a majority (57\%) of those responsible for PZJA fisheries. It could be important to also assess the perceptions of CFG members involved in the PZJA committees, and their views of the extent and form of TEK applied. Such an assessment would also capture the characteristics of TEK applied in primarily islander-driven comanagement processes that did not directly involve fishery managers and scientists. The TDMPs and harvest strategies for hand collectables are cases in point: neither was mentioned in detail by the survey respondents.

Our study provides further empirical evidence for Garibaldi and Turner's (2004) concept of cultural keystone species, and their role in promoting linkages and understandings between TEK and SMK. Green and hawksbill turtles and dugong (CV = 9) clearly qualify as cultural keystone species, being fundamental to Ailan Kastom. Lobsters $(\mathrm{CV}=8)$ and trochus $(\mathrm{CV}=7)$ also qualify, but to a lesser degree. However, our results suggest two additional components to this concept. First, turtle and dugong have catalyzed comanagement because of their cross-cultural values for islanders' livelihoods and government conservation imperatives for these species. Second, there is circumstantial evidence that they have also precipitated comanagement in other lesser keystone species. For example, the establishment of the ranger program was an impetus for the Hand Collectables WG to develop communitybased management of bêche-de-mer and trochus.
Because of their extensive ranges and the ecosystem services that they provide to local, national, and international beneficiaries, large and iconic marine fauna often generate cross-scale governance partnerships necessary for their management (e.g., Armitage 2005b, Wilson 2006, Armitage 2007). Such comanagement is particularly necessary when stakeholders hold conflicting values for the services provided by a species (Butler et al. 2006, 2008, 2011, Thompson et al. 2007, Butler 2011, Young et al. 2012). Turtles and dugong bear these characteristics. Green turtles in the Torres Strait are known to be part of the northern Great Barrier Reef stock (Limpus 2008). Dugong also migrate widely in Australian tropical waters, possibly driven by changes in seagrass abundance (Marsh et al. 2002, Sheppard et al. 2006). Their migratory behavior has necessitated cross-scale partnerships between multiple indigenous communities, state and national government agencies (Kennett et al. 2004, Wohling 2009), and cross-border collaboration between Australian and PNG stakeholders in the Torres Strait (DEC 2009). Applying the Millennium Ecosystem Assessment's (2005) terminology, islanders derive "provisioning" and "cultural" ecosystem services from these species through hunting, while their national and international biodiversity, and "cultural" ecosystem service, values have led to concerns among governments and scientists about the impacts of harvesting on the populations' viability (Heinsohn et al. 2004, Marsh et al. 2004, Limpus 2008). These factors, combined with scientists' and islanders' conflicting perceptions of the status of turtle and dugong populations (Johannes and Neis 2007), have amplified the necessity for comanagement.

We accept that there may be other factors influencing our results. Related to the influence of ecological scale, the geographical scale and economic value of commercial fisheries within the Torres Strait may also have mediated the 
application of TEK. The lobster fishery is the primary source of fishery-related income for islanders, and contributes to livelihoods across many communities (van Putten et al. 2012), motivating islanders to gain greater control and access to the fishery through comanagement (Mulrennan 2007). By comparison, trochus and bêche-de-mer fisheries are of low economic value and focused in the eastern islands (PZJA 2008, Wilson et al. 2009). Similarly, commercial finfish are of low value (PZJA 2008, Wilson et al. 2009). In spite of 53\% islander representation on finfish PZJA committees, comanagement is relatively undeveloped, and TEK has not been applied.

Another factor may be the differing power dynamics in PZJA committees, both among and between islander and government representatives, which may distort the degree of power-sharing otherwise indicated by the balance of committee members. Power dynamics are recognized to be highly influential in the comanagement process, and the balance within forums can determine the extent of knowledge integration and social networking (Wilson et al. 2006, Doubleday 2007, Nadasdy 2007, Pinkerton 2009). Such dynamics are particularly evident in the interface between TEK and SMK, where modes of communication and mistrust can impede negotiation between indigenous and government actors (Moller et al. 2004, Davidson-Hunt 2006, Foale 2006, Carter and Hill 2007, Gratani et al. 2011). In the Torres Strait it has also been recognized that logistical costs often prevent CFG representatives from attending PZJA meetings (PZJA 2008, Australian Senate 2010), potentially influencing the balance of power during decision making.

The question presents itself as to why cultural values, comanagement, and power-sharing status explain the pattern of TEK application in the Torres Strait better than stock collapses, limited SMK, and community ownership as observed in other Melanesian regions. The explanation may lie in the socio-political context of the Torres Strait, where indigenous resource use rights and Ailan Kastom have been subsumed and suppressed by Australian law and economy since the 19th century. Since the signing of the Treaty in 1985, which explicitly aims to protect the traditional livelihoods and practices of islanders, and thus promotes comanagement, there has been a revival of Ailan Kastom, characterized by the Regional Sea Claim lodged in 2001. This represents the most recent progression of islanders' claims to resource sovereignty following the Mabo Decision in 1992 (Scott and Mulrennan 1999). In this context the application of TEK through the comanagement of cultural keystone species may be indicative of reasserted ownership and control, as also observed among First Nation groups in North America (e.g. Armitage 2005a, 2007, Jones 2007, Poepoe et al. 2007, Jones et al. 2010). By comparison, although also colonized by Europeans, many developing Melanesian nations gained independence in the late 20th century, and marine tenure and customary practices have remained largely intact (Johannes 2002). Hence, in these situations the application of TEK may be associated more with the necessity of managing fisheries in the absence of SMK, facilitated by a stronger cultural recognition of TEK by formal and informal institutions, rather than the politics of resource ownership.

\section{CONCLUSION}

The application of TEK and SMK in natural resource management potentially enhances the resilience of socialecological systems by providing a diversity of knowledge for problem solving and related cross-scale and adaptive governance networks (Folke 2004, Folke et al. 2005, Berkes and Turner 2006, Davidson-Hunt 2006, Berkes 2009). Our results show that in the Torres Strait, TEK in the form of local knowledge of species has only recently been applied in the comanagement of cultural keystone species. Survey respondents provided little evidence of the application of higher levels of TEK as defined by Berkes (1999), such as management systems, social institutions, or worldviews within which they are embedded. However, provisions for turtles and dugong set out in the TDMPs clearly include measures akin to these, such as management areas based on customary sea tenure, seasonal closures, and hunting and butchering methods that comply with traditional norms. Prototype community-based harvest strategies for hand collectables also aim to restore traditional spatial management systems.

Further application of TEK and its integration with SMK to develop more effective hybrid management systems may depend upon the ability of the PZJA to modify the consultative committee structure to promote equitable islander and government agency representation. This should include the establishment of new forums for traditional turtle, dugong, and reef fisheries, as recommended by a recent review of Torres Strait fisheries management (AFMA 2010). Such forums should encourage experimentation, innovation and learning among all representatives, and hence potentially allow adaptive comanagement to evolve. This would encourage the contemporary extent and characteristics of TEK to emerge. In addition, forums should enable the mutual testing and validation of TEK and SMK in the Torres Strait, an important step in knowledge integration (Gratani et al. 2011) that so far is not evident in fishery management processes.

Evolution from comanagement to adaptive comanagement and more extensive knowledge integration is most likely to occur for turtles and dugong because implementation of TDMPs from 2008 represented the start of the integration stage of comanagement for these species. Responding to their ecological scale, governance structures for turtles and dugong are already instigating international collaboration between Australian and PNG communities and government (DEC 2009). This may catalyze similar initiatives for other shared marine resources. Hence, our study highlights the potentially 
important role of cultural keystone species in stimulating adaptive, cross-cultural, and cross-scale resource governance in developed economies such as Australia, where indigenous groups remain a minority.

Such governance may become increasingly important for managing the resilience of tropical social-ecological systems in northern Australia (Bohensky et al. 2011, Gooch et al. 2012). Exogenous drivers such as climate change-induced sea level rise (Green et al. 2010), immigration to Torres Strait from PNG, shipping traffic, illegal foreign fishing, and rising fuel prices are having a growing impact on the region (TSRA 2009). Consequently the future of the Torres Strait is becoming increasingly uncertain. TEK may become a key component of adaptation to future change, but further implementation, experimentation, and evaluation is required to fully establish its role.

Responses to this article can be read online at: http://www.ecologyandsociety.org/issues/responses. php/5165

\section{Acknowledgments:}

This study was funded by the Australian Government's Department of Environment, Water, Heritage and the Arts Marine and Tropical Science Research Facility. The contribution of surveyed Torres Strait managers and researchers is also gratefully acknowledged. Sara Busilacchi, Nicole Murphy, Leanne Cullen-Unsworth, Kirsten Maclean, Ingrid van Putten, Erin Bohensky, Jocelyn Davies, and two anonymous reviewers provided constructive comments that improved the paper.

\section{LITERATURE CITED}

Aikenhead, G. S., and M. Ogawa. 2007. Indigenous knowledge and science revisited. Cultural Studies of Science Education 2:539-620. http://dx.doi.org/10.1007/s11422-007-9067-8

Armitage, D. 2005a. Adaptive capacity and community-based natural resource management. Environmental Management 35:703-715. http://dx.doi.org/10.1007/s00267-004-0076-z

Armitage, D. 2005b. Community-based narwhal management in Nunavut, Canada: change, uncertainty, and adaptation. Society \& Natural Resources 18:715-731. http://dx.doi. org/10.1080/08941920591005124

Armitage, D. 2007. Building resilient livelihoods through adaptive co-management: the role of adaptive capacity. Pages 62-82 in D. Armitage, F. Berkes, and N. Doubleday, editors. Adaptive co-management: collaboration, learning, and multilevel governance. UBC Press, Vancouver, British Columbia, Canada.
Armitage, D. R., R. Plummer, F. Berkes, R. I. Arthur, A. T. Charles, I. J. Davidson-Hunt, A. P. Diduck, N. C. Doubleday, D. S. Johnson, M. Marschke, P. McCooney, E. W. Pinkerton, and E. K. Wollenberg. 2009. Adaptive co-management for social-ecological complexity. Frontiers in Ecology and Environment 7:95-102. http://dx.doi.org/10.1890/070089

Aswani, S. 1999. Common property models of sea tenure: a case study from the Roviana and Vonavona lagoons, New Georgia, Solomon Islands. Human Ecology 27:417-453. http://dx.doi.org/10.1023/A:1018727607651

Aswani, S., S. Albert, A. Sabetian, and T. Furusawa. 2007. Customary management as precautionary and adaptive principles for protecting coral reefs in Oceania. Coral Reefs 26:1009-1021. http://dx.doi.org/10.1007/s00338-007-0277$\underline{Z}$

Australian Fisheries Management Authority (AFMA). 2010. Annual Report 2009-10. AFMA, Canberra, Australia. [online] URL: http://www.afma.gov.au/about-us/afma-annual-reports/ annual-report-2009-2010/

Australian Senate. 2010. Official Committee Hansard. Reference: matters relating to the Torres Strait region. Australian Senate, Canberra, Australia. [online] URL: http:// parlinfo.aph.gov.au/parlInfo/download/committees/commsen/13195/ toc pdf/7720-2.pdf;fileType=application/pdf\#search $=\% 22$ Matters $\%$ 20relating\%20to\%20the \%20Torres\%20Strait\%20region\%22

Barham, A. J. 2000. Late Holocene maritime societies in the Torres Strait Islands, northern Australia - cultural arrival or cultural emergence? Pages 223-314 in S. O'Connor and P. Veth, editors. East of Wallace's Line: studies of past and present maritime cultures of the Indo-Pacific region. Balkema Press, Rotterdam, Netherlands.

Beckett, J. 1987. Torres Strait Islanders: custom and colonialism. Cambridge University Press, Cambridge, UK.

Berkes, F. 1999. Sacred ecology. Traditional ecological knowledge and resource management. Taylor and Francis, Philadelphia, USA.

Berkes, F. 2009. Evolution of co-management: role of knowledge generation, bridging organizations and social learning. Journal of Environmental Management 90:1692-1702. http://dx.doi.org/10.1016/j.jenvman.2008.12.001

Berkes, F., and N. J. Turner. 2006. Knowledge, learning and the evolution of conservation practice for social-ecological system resilience. Human Ecology 34:479-494. http://dx.doi. org/10.1007/s10745-006-9008-2

Bohensky, E., J. R. A. Butler, R. Costanza, I. Bohnet, A. Delisle, K. Fabricius, M. Gooch, I. Kubiszewski, G. Lukacs, P. Pert, and E. Wolanski. 2011. Future takers or future makers? 
A scenario analysis of climate change and the Great Barrier Reef. Global Environmental Change 21:876-893. http://dx. doi.org/10.1016/j.gloenvcha.2011.03.009

Bohensky, E. L., and Y. Maru. 2011. Indigenous knowledge, science, and resilience: what have we learned from a decade of international literature on "integration"? Ecology and Society 16(4): 6. http://dx.doi.org/10.5751/ES-04342-160406

Brook, R. K., and S. M. McLachlan. 2008. Trends and prospects for local knowledge in ecological and conservation research and monitoring. Biodiversity and Conservation 17:3501-3512. http://dx.doi.org/10.1007/s10531-008-9445$\underline{x}$

Busilacchi, S. 2008. The subsistence coral reef fish fishery in the Torres Strait: monitoring protocols and assessment. Dissertation, James Cook University, Townsville, Australia.

Butler, J. R. A. 2011. The challenge of knowledge integration in the adaptive co-management of conflicting ecosystem services provided by seals and salmon. Animal Conservation 14:599-601. http://dx.doi.org/10.1111/j.1469-1795.2011.00509. $\mathrm{x}$

Butler, J. R. A., S. J. Middlemas, I. M. Graham, and R. N. Harris. 2011. Perceptions and costs of seal impacts on salmon and sea trout fisheries in the Moray Firth, Scotland: implications for the adaptive co-management of Special Areas of Conservation. Marine Policy 35:317-323. http://dx.doi. org/10.1016/j.marpol.2010.10.011

Butler, J. R. A., S. J. Middlemas, I. M. Graham, P. M. Thompson and J. D. Armstrong. 2006. Modelling the impacts of removing seal predation from Atlantic salmon, Salmo salar, rivers in Scotland: a tool for targeting conflict resolution. Fisheries Management and Ecology 13:285-291. http://dx. doi.org/10.1111/j.1365-2400.2006.00504.X

Butler, J. R. A., S. J. Middlemas, S. A. McKelvey, I. McMyn, B. Leyshon, I. Walker, P. M. Thompson, I. L. Boyd, C. Duck, J. D. Armstrong, I. M. Graham, and J. M. Baxter. 2008. The Moray Firth Seal Management Plan: an adaptive framework for balancing the conservation of seals, salmon, fisheries and wildlife tourism in the UK. Aquatic Conservation: Marine and Freshwater Ecosystems 18:1025-1038. http://dx.doi.org/10.1002/ aqc. 923

Carlsson, L., and F. Berkes. 2005. Co-management: concepts and methodological implications. Journal of Environmental Management 75:65-76. http://dx.doi.org/10.1016/j. jenvman.2004.11.008

Carter, J., and G. Hill. 2007. Indigenous community-based fisheries in Australia. Journal of Environmental Management 85:866-875. http://dx.doi.org/10.1016/j.jenvman.2006.10.021
Cinner, J. E., and S. Aswani. 2007. Integrating customary management into marine conservation. Biological Conservation 140:201-216. http://dx.doi.org/10.1016/j.biocon.2007.08.008

Cinner, J. E., M. J. Marnane, and T. R. McClanahan. 2005. Conservation and community benefits from traditional coral reef management at Ahus Island, Papua New Guinea. Conservation Biology 19:1714-1725. http://dx.doi.org/10.1111/ j.1523-1739.2005.00209.x-i1

Cinner, J., S. G. Sutton, and T. G. Bond. 2007. Socioeconomic thresholds that affect use of customary fisheries management tools. Conservation Biology 21:1603-1611.

Cordell, J. 1995. Indigenous management of land and sea and traditional activities in Cape York Peninsula. University of Queensland Report for the Cape York Land Use Strategy, Brisbane, Australia.

Davidson-Hunt, I. J. 2006. Adaptive learning networks: developing resource management knowledge through social learning forums. Human Ecology 34:593-614. http://dx.doi. org/10.1007/s10745-006-9009-1

Department of Environment and Conservation (DEC). 2009. A framework to support the sustainable management of marine turtles and dugongs in the Western Province, PNG. DEC, Port Moresby, Papua New Guinea.

De Vaus, D. A. 2002. Surveys in social research. Allen and Unwin, Sydney, Australia.

Doubleday, N. 2007. Culturing adaptive co-management: finding 'keys' to resilience in asymmetries of power. Pages 228-248 in D. Armitage, F. Berkes, and N. Doubleday, editors. Adaptive co-management: collaboration, learning, and multilevel governance. UBC Press, Vancouver, British Columbia, Canada.

Drew, J. A. 2005. Use of traditional ecological knowledge in marine conservation. Conservation Biology 19:1286-1293. http://dx.doi.org/10.1111/j.1523-1739.2005.00158.x

Dulvy, N. K., and N. V. C. Polunin. 2004. Using informal knowledge to infer human-induced rarity of a conspicuous reef fish. Animal Conservation 7:365-374. http://dx.doi. org/10.1017/S1367943004001519

Foale, S. 2006. The intersection of scientific and indigenous ecological knowledge in coastal Melanesia: implications for contemporary marine resource management. International Social Science Journal 58:129-137. http://dx.doi.org/10.1111/ j.1468-2451.2006.00607.x

Foale, S., P. Cohen, S. Januchowski-Hartley, A. Wenger, and M. Macintyre. 2010. Tenure and taboos: origins and implications for fisheries in the Pacific. Fish and Fisheries 21:1-13. 
Foale, S., and B. Manele. 2004. Social and political barriers to the use of marine protected areas for conservation and fishery management in Melanesia. Asia Pacific Viewpoint 45:373-386. http://dx.doi.org/10.1111/j.1467-8373.2004.00247. $\underline{\mathrm{X}}$

Folke, C. 2004. Traditional knowledge in social-ecological systems. Ecology and Society 9(3): 7. [online] URL: http:// www.ecologyandsociety.org/vol9/iss3/art7/

Folke, C., T. Hahn, P. Olsson, and J. Norberg. 2005. Adaptive governance of social-ecological systems. Annual Review of Environment and Resources 30:441-473. http://dx.doi. org/10.1146/annurev.energy.30.050504.144511

Garibaldi, A., and N. Turner. 2004. Cultural keystone species: implications for ecological conservation and restoration. Ecology and Society 9(3): 1. [online] URL: http://www. ecologyandsociety.org/vol9/iss3/art1/

Gooch, M., J. R. A. Butler, L. C. Cullen-Unsworth, D. Rigano, and C. Manning. 2012. Community-derived indicator domains for social resilience to water quality decline in a Great Barrier Reef catchment, Australia. Society \& Natural Resources 25:421-439. http://dx.doi.org/10.1080/08941920.2011.608183

Granek, E. F., and M. A. Brown. 2005. Co-management approach to marine conservation in Mohéli, Comoros Islands. Conservation Biology 19:1724-1732. http://dx.doi.org/10.1111/ j.1523-1739.2005.00301.x

Gratani, M., J. R. A. Butler, F. Royee, D. Burrows, P. Valentine, and W. I. Canendo. 2011. Is validation of indigenous ecological knowledge a disrespectful process? A case study of traditional fishing poisons and invasive fish management from the Wet Tropics, Australia. Ecology and Society 16(3): 25. http://dx.doi.org/10.5751/ES-04249-160325

Green, D., L. Alexander, K. Mclnnes, J. Church, N. Nicholls, and N. White. 2010. An assessment of climate change impacts and adaptation for the Torres Strait Islands, Australia. Climate Change 102:405-433. http://dx.doi.org/10.1007/s10584-009-9756-2

Haggan, N., B. Neis, and I. G. Baird. 2007. Introduction: putting fishers' knowledge to work. Pages 35-40 in N. Haggan, B. Neis, and G. Baird, editors. Fishers' knowledge in fisheries science and management. Coastal Management Sourcebooks 4, UNESCO, Paris, France.

Harris, A., G. Dews, I. Poiner, and J. Kerr. 1994. The traditional and island based catch of the Torres Strait Protected Zone. Final Report on CSIRO Research 1990-1993. CSIRO Division of Fisheries, Hobart, Australia.

Heinsohn, R., R. C. Lacy, D. B. Lindenmayer, H. Marsh, D. Kwan, and I. R. Lawler. 2004. Unsustainable harvest of dugongs in Torres Strait and Cape York (Australia) waters: two case studies using population viability analysis. Animal Conservation 7:417-425. http://dx.doi.org/10.1017/ $\underline{\mathrm{S} 1367943004001593}$

Hickey, F. R. 2007. Traditional resource management in Vanuatu: worldviews in transformation. Pages 147-1686 in N. Haggan, B. Neis, and G. Baird, editors. Fishers'knowledge in fisheries science and management. Coastal Management Sourcebooks 4, UNESCO, Paris, France.

Johannes, R. E. 1998a. The case for data-less marine resource management: examples from tropical nearshore finfisheries. Trends in Ecology \& Evolution 13:243-246. http://dx.doi. org/10.1016/S0169-5347(98)01384-6

Johannes, R. E. 1998b. Government-supported, village-based management of marine resources in Vanuatu. Ocean \& Coastal Management 40:165-186. http://dx.doi.org/10.1016/ $\underline{\text { S0964-5691(98)00046-5 }}$

Johannes, R. E. 2002. The renaissance of community-based marine resource management in Oceania. Annual Review of Ecology and Systematics 33:317-340. http://dx.doi. org/10.1146/annurev.ecolsys.33.010802.150524

Johannes, R. E., M. M. R. Freeman, and R. J. Hamilton. 2000. Ignore fishers' knowledge and miss the boat. Fish and Fisheries 1:257-271. http://dx.doi.org/10.1111/ j.1467-2979.2000.00019.x

Johannes, R. E., and F. R. Hickey. 2004. Evolution of villagebased marine resource management in Vanuatu between 1993 and 2001. Coastal Region and Small Island Papers 15, UNESCO, Paris, France.

Johannes, R. E., and W. MacFarlane. 1991. Traditional fishing in the Torres Strait Islands. CSIRO, Hobart, Australia.

Johannes, R. E., and B. Neis. 2007. The value of anecdote. Pages 41-58 in N. Haggan, B. Neis, and G. Baird, editors. Fishers' knowledge in fisheries science and management. Coastal Management Sourcebooks 4, UNESCO, Paris, France.

Jones, R. 2007. Application of Haida oral history to Pacific herring management. Pages 103-118 in N. Haggan, B. Neis, and G. Baird, editors. Fishers' knowledge in fisheries science and management. Coastal Management Sourcebooks 4, UNESCO, Paris, France.

Jones, A., B. Barnett, A. J. Williams, J. Grayson, S. Busilacchi, A. Duckworth, E. Evans-Illidge, G. A. Begg, and C. D. Murchie. 2008. Effective communication tools to engage Torres Strait Islanders in scientific research. Continental Shelf Research 28:2350-2356. http://dx.doi.org/10.1016/j.csr.2008.03.027 
Jones, R., C. Rigg, and L. Lee. 2010. Haida marine planning: First Nations as partners in marine conservation. Ecology and Society 15(1): 12. [online] URL: http://www.ecologyandsociety. org/vol15/iss1/art12/

Kennett, R., N. Munungurritj, and D. Yunupingu. 2004. Migration patterns of marine turtles in the Gulf of Carpentaria northern Australia: implications for Aboriginal management. Wildlife Research 31:241-248. http://dx.doi.org/10.1071/ $\underline{\text { WR03002 }}$

Kuperan, K., N. M. R. Abdullah, R. S. Pomeroy, E. L. Genio, and A. M. Salamanca. 2008. Measuring transaction costs of fisheries co-management. Coastal Management 36:225-240. http://dx.doi.org/10.1080/08920750701681991

Kwan, D., G. Dews, M. Bishop, and H. Garnier. 2001. Towards community-based management of natural marine resources in Torres Strait. Pages 214-230 in R. Baker, J. Davies, and E. Young, editors. Working on country: contemporary indigenous management of Australia's lands and coastal regions. Oxford University Press, Melbourne, Australia.

Kwan, D., H. Marsh, and S. Delean. 2006. Factors influencing the sustainability of customary dugong hunting by a remote indigenous community. Environmental Conservation 33:164-171.

Limpus, C. J. 2008. A biological review of Australian marine turtles. 2. Green turtle Chelonia mydas (Linnaeus). Queensland Environment Protection Agency, Brisbane, Australia.

Limpus, C. J. 2009. A biological review of Australian marine turtles 3. Hawksbill turtle Eretmochelys imbricata (Linnaeus). Queensland Environment Protection Agency, Brisbane, Australia.

MacLaren, G. 2012. TEK system workshop overview. Environmental Systems Solutions and Torres Strait Regional Authority, Thursday Island, Australia.

Marsh, H., I. R. Lawler, D. Kwan, S. Delean, K. Pollock, and M. Alldredge. 2004. Aerial surveys and the potential biological removal technique indicate that the Torres Strait dugong fishery is unsustainable. Animal Conservation 7:435-443. http://dx.doi.org/10.1017/S1367943004001635

Marsh, H., H. Penrose, C. Eros, and J. Hughes. 2002. Dugong: status reports and action plans for countries and territories. UNEP Early Warning Assessment Report Series 1, UNEP, Nairobi, Kenya.

McConney, P., R. Mahon, and R. Pomeroy. 2007. Challenges facing resource management in the Caribbean. Pages 105-124 in D. Armitage, F. Berkes, and N. Doubleday, editors. Adaptive co-management: collaboration, learning, and multilevel governance. UBC Press, Vancouver, British Columbia, Canada.
McNiven, I. J., and R. Feldman. 2003 Ritual orchestration of seascapes: hunting magic and dugong bone mounds in Torres Strait, NE Australia. Cambridge Archaeological Journal 13:169-94. http://dx.doi.org/10.1017/S0959774303000118

McNiven, I. J., and G. Hitchcock. 2004. Torres Strait Islander marine subsistence specialisation and terrestrial animal translocation. Pages 105-162 in I. J. McNiven and M. Quinnell, editors. Torres Strait archaeology and material culture. Memoirs of the Queensland Museum Cultural Heritage Series, 3 (Part 1), Brisbane, Australia.

Mellors, J. E., L. J. McKenzie, and R. G. Coles. 2008. Seagrass-Watch: engaging Torres Strait Islanders in marine habitat monitoring. Continental Shelf Research 28:2339-2349. http://dx.doi.org/10.1016/j.csr.2008.03.041

Millennium Ecosystem Assessment. 2005. Ecosystems and human well-being: a framework for assessment. Island Press, Washington, D.C., USA.

Moller, H., F. Berkes, P. O. Lyver, and M. Kislalioglu. 2004. Combining science and traditional ecological knowledge: monitoring populations for co-management. Ecology and Society 9(3): 2. [online] URL: http://www.ecologyandsociety. org/vol9/iss3/art2

Mulrennan, M. E. 2007. Sustaining a small boat fishery: recent developments and future prospects for Torres Strait Islanders, northern Australia. Pages 183-198 in N. Haggan, B. Neis, and G. Baird, editors. Fishers'knowledge in fisheries science and management. Coastal Management Sourcebooks 4, UNESCO, Paris, France.

Mulrennan, M., and C. Scott. 2000. Mare Nullius: indigenous rights in saltwater environments. Development and Change 31:681-708. http://dx.doi.org/10.1111/1467-7660.00172

Mulrennan, M. E., and C. Scott. 2001. Indigenous rights and control of the sea in the Torres Strait. Indigenous Law Bulletin 5:11-45.

Mulrennan, M. E., and C. Scott. 2005. Co-management: an attainable partnership? Two cases from James Bay, Quebec and Torres Strait, Queensland. Anthropologia 47:197-213.

Nadasdy, P. 2007. Adaptive co-management and the gospel of resilience. Pages 208-227 in D. Armitage, F. Berkes, and N. Doubleday, editors. Adaptive co-management: collaboration, learning, and multi-level governance. UBC Press, Vancouver, British Columbia, Canada.

Nietschmann, B. 1984. Hunting and ecology of dugongs and green turtles in Torres Strait. National Geographic Society Research Reports 17:625-651.

Nietschmann, B. 1989. Traditional sea territories, resources and rights in Torres Strait. Pages 60-94 in J. Cordell, editor. 
A sea of small boats. Cultural Survival, Cambridge, Massachusetts, USA.

Northern Australian Indigenous Land and Sea Management Alliance (NAILSMA). 2005. Dugong and marine turtle knowledge handbook: indigenous and scientific knowledge of dugong and marine turtles in northern Australia. Tropical Savannas Cooperative Research Centre, Darwin, Australia.

Olsson, P., C. Folke, and F. Berkes. 2004. Adaptive comanagement for building resilience in social-ecological systems. Environmental Management 34:75-90. http://dx.doi. org/10.1007/s00267-003-0101-7

Pinkerton, E. 2009. Coastal marine systems: conserving fish and sustaining community livelihoods with co-management. Pages 241-257 in F. S. Chapin, III, G. P. Kofinas, and C. Folke, editors. Principles of ecosystem stewardship: resilience-based natural resource management in a changing world. Springer Science+Business Media, New York, New York, USA. http:// dx.doi.org/10.1007/978-0-387-73033-2_11

Plummer, R. 2006. Sharing the management of a river corridor: a case study of the co-management process. Society \& Natural Resources 19:709-721. http://dx.doi. org/10.1080/08941920600801132

Plummer, R. 2009. The adaptive co-management process: an initial synthesis of representative models and influential variables. Ecology and Society 14(2): 24. [online] URL: http:// www.ecologyandsociety.org/vol14/iss2/art24/

Plummer, R., and D. R. Armitage. 2007a. Charting the new territory of adaptive co-management: a Delphi study. Ecology and Society 12(2): 10. [online] URL: http://www. ecologyandsociety.org/vol12/iss2/art10/

Plummer, R., and D. R. Armitage. 2007b. A resilience-based framework for evaluating adaptive co-management: linking ecology, economics and society in a complex world. Ecological Economics 61:62-74. http://dx.doi.org/10.1016/j. ecolecon.2006.09.025

Poepoe, K. K., P. K. Bartram, and A. M. Friedlander. 2007. The use of traditional knowledge in the contemporary management of a Hawaiian community's marine resources. Pages 119-144 in N. Haggan, B. Neis, and G. Baird, editors, Fishers' knowledge in fisheries science and management. Coastal Management Sourcebooks 4, UNESCO, Paris, France.

Pomeroy, R. 2007. Conditions for successful fisheries and coastal resources co-management: lessons learned in Asia, Africa, and the wider Caribbean. Pages 172-187 in D. Armitage, F. Berkes, and N. Doubleday, editors. Adaptive comanagement: collaboration, learning, and multi-level governance. UBC Press, Vancouver, British Columbia, Canada.
Pomeroy, R. S., and R. Rivera-Guieb. 2005. Fishery comanagement: a practical handbook. CABI, Wallingford, UK. http://dx.doi.org/10.1079/9780851990880.0000

Protected Zone Joint Authority (PZJA). 2004. Torres Strait Fisheries Management Advisory Committee Recommendations. PZJA, Canberra, Australia. [online] URL: http://pzja.gov.au/ wp-content/uploads/2011/06/TSFMAC-3-Meeting-7-9July-2004 Record-of-decisions.pdf

Protected Zone Joint Authority (PZJA). 2005. Torres Strait Fisheries Management Advisory Committee Meeting - No. 5: Recommendations from the TSFMAC. PZJA, Canberra, Australia. [online] URL: http://pzja.gov.au/wp-content/ uploads/2011/06/TSFMAC-5-Meeting-24-25-May-2005 Recordof-decisions.pdf

Protected Zone Joint Authority (PZJA). 2007. Hand Collectables Working Group Minutes, 9-10 October 2007, Thursday Island. PZJA, Canberra, Australia.

Protected Zone Joint Authority (PZJA). 2008. Annual Report 2007-2008. Australian Fisheries Management Authority on behalf of the PZJA, Canberra, Australia. [online] URL: http:// pzja.gov.au/wp-content/uploads/2011/06/Annual-Report-2007-2008. pdf

Scott, C., and M. Mulrennan. 1999. Land and sea tenure at Erub, Torres Strait: property, sovereignty and the adjudication of cultural continuity. Oceania 70:146-176.

Sharpe, N. 1992. Footprints along the Cape York sandbeaches. Aboriginal Studies Press, Canberra, Australia.

Sheppard, J. K., A. R. Preen, H. Marsh, I. R. Lawler, S. D. Whiting, and R. E. Jones. 2006. Movement heterogeneity of dugongs, Dugong dugon (Müller) over large spatial scales. Journal of Experimental Marine Biology and Ecology 334:64-83. http://dx.doi.org/10.1016/j.jembe.2006.01.011

Skewes, T. D., A. G. Kingston, D. R. Jacobs, C. R. Pitcher, M. Bishop, C. M. Burridge, and S. Lilly. 2002. The traditional fisheries catch of Torres Strait Islanders. Project Final Report, 1996-2001. AFMA/CSIRO Division of Marine Research Final Report, Canberra, Australia.

Smyth, D., J. Fitzpatrick, and D. Kwan. 2006. Towards the development of cultural indicators for marine resource management in the Torres Strait. Torres Strait Cooperative Research Centre Report, Townsville, Australia.

Tawake, L., J. R. A. Butler, T. Skewes, V. McGrath, and F. Morseu. 2010. Towards regional and community-scale reporting of ecosystem health in the Torres Strait. Report to the Marine and Tropical Science Research Facility. CSIRO Ecosystem Sciences, St. Lucia, Queensland, Australia.

Tawake, A., J. Parks, P. Radikedike, B. Aalbersberg, V. Vuki, and N. Salafsky. 2001. Harvesting clams and data: Involving 
local communities in monitoring can lead to conservation success in all sorts of unanticipated ways: a case in Fiji. Conservation in Practice 2:32-35. http://dx.doi.org/10.1111/ j.1526-4629.2001.tb00020.x

Thompson, P. M., B. Mackey, T. M. Barton, C. Duck, and J. R. A. Butler. 2007. Assessing the potential impact of salmon fisheries management on the conservation status of harbour seals (Phoca vitulina) in north-east Scotland. Animal Conservation 10:48-56. http://dx.doi.org/10.1111/ j.1469-1795.2006.00066.x

Torres Strait Regional Authority (TSRA). 2005. Torres Strait Land and Sea Management Strategy. TSRA, Thursday Island, Australia.

Torres Strait Regional Authority (TSRA). 2009. Torres Strait and Northern Peninsula Area regional plan. Planning for our future: 2009 to 2029. TSRA, Thursday Island, Australia.

van Putten, I., A. Lalancette, P. Bayliss, D. Dennis, T. Hutton, A. Norman-Lopéz, S. Pascoe, E. Plagányi, and T. Skewes. 2012. A Bayesian model of factors influencing indigenous participation in the Torres Strait tropical rock lobster fishery. Marine Policy 37:96-105. http://dx.doi.org/10.1016/j. marpol.2012.04.001

Vierros, M., A. Tawake, F. Hickey, A. Tiraa, and R. Noa. 2010. Traditional marine management areas of the Pacific in the context of national and international law and policy. United Nations University Traditional Knowledge Initiative, Darwin, Australia.

Weiss, K., M. Hamann, M. Kinney, and H. Marsh. 2012. Knowledge exchange and policy influence in a marine resource governance network. Global Environmental Change 22:178-188. http://dx.doi.org/10.1016/j.gloenvcha.2011.09.007

Williams, A. J., A. C. Ballagh, G. A. Begg, C. D. Marchie, and L. M. Currey. 2008. Harvest patterns and effort dynamics of indigenous and non-indigenous commercial sectors of the eastern Torres Strait reef line fishery. Continental Shelf Research 28:2117-2128. http://dx.doi.org/10.1016/j.csr.2008.03.030

Wilson, J. A. 2006. Matching social and ecological systems in complex ocean fisheries. Ecology and Society 11(1): 9. [online] URL: http://www.ecologyandsociety.org/vol11/iss1/ $\underline{\operatorname{art} 9 /}$

Wilson, D., R. Curtotti, G. Begg, and K. Phillips, editors. 2009, Fishery status reports 2008: status of fish stocks and fisheries managed by the Australian Government. Bureau of Rural Sciences and Australian Bureau of Agricultural and Resource Economics, Canberra, Australia.

Wilson, D. C., J. Raakjaer, and P. Degnbol. 2006. Local ecological knowledge and practical fisheries management in the tropics: a policy brief. Marine Policy 30:794-801. http:// dx.doi.org/10.1016/j.marpol.2006.02.004
Wohling, M. 2009. The problem of scale in indigenous knowledge: a perspective from northern Australia. Ecology and Society 14(1): 1. [online] URL: http://www. ecologyandsociety.org/vol14/iss1/art1/

Young, J. C., J. R. A. Butler, A. Jordan, and A. D. Watt. 2012. Less government intervention in biodiversity management: risks and opportunities. Biodiversity and Conservation 21:1095-1100. http://dx.doi.org/10.1007/s10531-012-0243-0 